\title{
Infected palmer and plantar pits: a rare presentation of Gorlin's syndrome
}

\author{
Thisara Weerasuriya, Raja Swaminathan \\ Orthopaedics Department, Tameside Hospital, Ashton-under-Lyne, Lancashire, UK
}

Correspondence to Mr Thisara Weerasuriya,drthisara@yahoo.co.uk

\section{DESCRIPTION}

Gorlin syndrome (basal cell nevus syndrome or nevoid basal cell carcinoma syndrome) is an uncommon but, well known, autosomal dominant cancer syndrome. ${ }^{1}$ This condition affects the hands commonly. ${ }^{2}$ However the hand is not the common presenting clinical feature. ${ }^{2}$ We wish to present an unusual presentation of Gorlin's syndrome which has not been noted in the literature previously, where the presentation involved simultaneous plantar as well as palmer pit infections resulting in abscess formation. A 50 -year-old lady presented to the accident and emergency department with recurrent palmer and planter abscesses (figure 1). The patient was aware of the condition she was ailing from and walked into the accident and emergency department with an article from a journal giving all details of Gorlin's syndrome. She had no history of trauma and was not a diabetic. She had an incision and drainage of a palmer pit abscess on her left non-dominant hand index finger and an incision and drainage of a planter pit abscess on ipsilateral foot. Microbiological analysis was negative and histology was compatible with Gorlin's syndrome. The patient had more than 200 basal cell carcinomatous lesions surgically excised previously. Keeping with the symptomatology of Gorlin's syndrome, the patient had a history of multiple jaw cysts, early onset osteoarthritis of the large joints, bifid ribs, repeated episodes of conjunctivitis and sensitivity to radiation. Following the surgical drainage of the palmer and planter abscesses she made an uneventful recovery. The genetic locus for Gorlin syndrome is 9 q22.3-q31, as determined with linkage analysis. ${ }^{3}$ Clinicians should be familiar with Gorlin syndrome because of the propensity of these patients to develop multiple neoplasms, including basal cell carcinomas and medulloblastoma, and because of the their extreme sensitivity to ionising radiation including sunlight ${ }^{1}$ and from an orthopaedic point of view it is important to be aware of this syndrome because of the presentation with palmer and planter pit abscesses. The early onset osteoarthritis is of concern for the orthopaedic surgeons. The hand and feet, though affected are not the most common presentation of Gorlin's syndrome. ${ }^{2}$ Regular follow-up of the patient, genetic counselling and follow-up of children with imaging for the development of medulloblastoma is important in caring for these patients ${ }^{2}$.
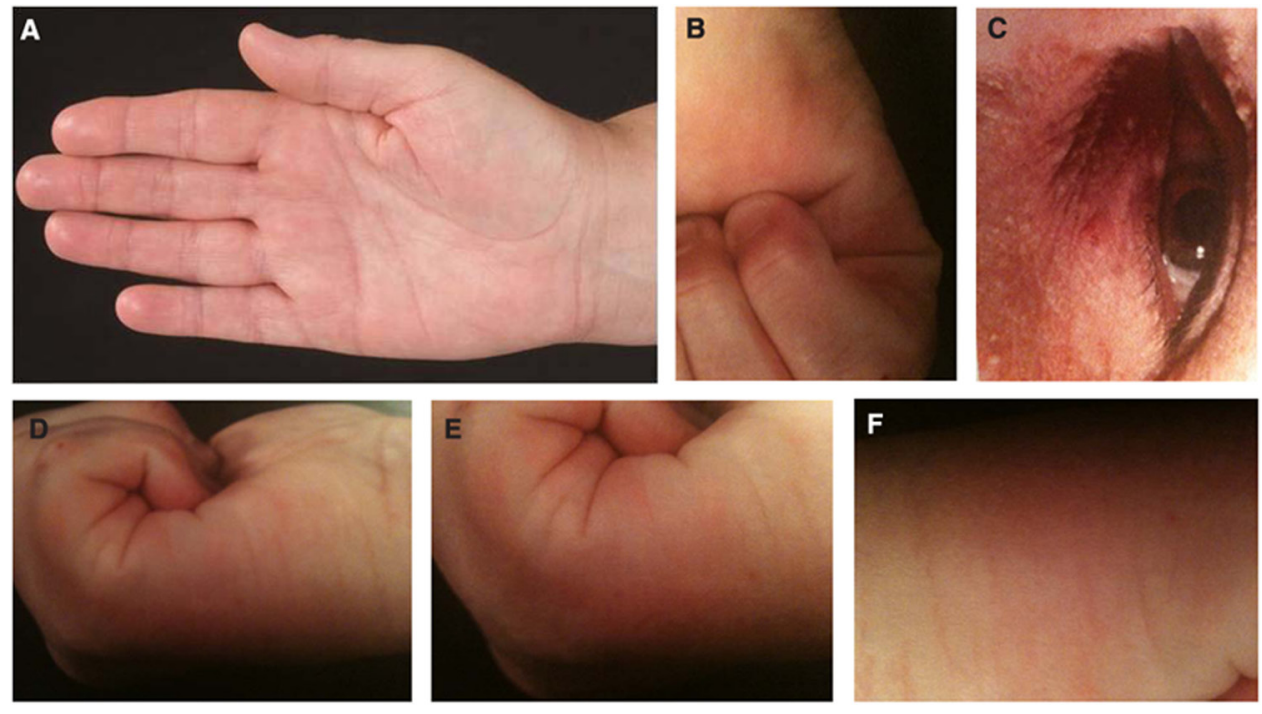

Figure 1 (A) Palmer pits seen in the hypothenar eminence and the tip of middle finger. (B) The palmer pit can be seen on the medial aspect of the palm. (C) Basal cell carcinoma near the eye. (D) Palmer pits. (E) Close up of palmer pits. (F) Plantar pit on the lateral border of the foot. 


\section{BMJ Case Reports}

Competing interests None.

Patient consent Obtained.

\section{REFERENCES}

1. Lo Muzio L. Nevoid basal cell carcinoma syndrome (Gorlin syndrome). Orphanet J Rare Dis 2008;3:32.
2. Nassab R. Infected palmer pits: a rare presentation of Gorlin's syndrome. J hand Surgery (British and European Volume) 2005:30:459.

3. Gailani MR, Bale SJ, Leffell DJ, et al. Developmental defects in Gorlin syndrome related to a putative tumor suppressor gene on chromosome 9. Cell 1992:69:111-7.

4. Bale AE. The nevoid basal cell carcinoma syndrome: genetics and mechanism of carcinogenesis. Cancer Invest 1997;15:180-6.

This pdf has been created automatically from the final edited text and images.

Copyright 2011 BMJ Publishing Group. All rights reserved. For permission to reuse any of this content visit http://group.bmj.com/group/rights-licensing/permissions.

BMJ Case Report Fellows may re-use this article for personal use and teaching without any further permission.

Please cite this article as follows (you will need to access the article online to obtain the date of publication).

Weerasuriya T, Swaminathan R. Infected palmer and plantar pits: a rare presentation of Gorlin's syndrome. BMJ Case Reports 2011;

10.1136/bcr.05.2011.4237, date of publication

Become a Fellow of BMJ Case Reports today and you can:

- Submit as many cases as you like

- Enjoy fast sympathetic peer review and rapid publication of accepted articles

- Access all the published articles

- Re-use any of the published material for personal use and teaching without further permission

For information on Institutional Fellowships contact consortiasales@bmjgroup.com

Visit casereports.bmj.com for more articles like this and to become a Fellow 